Hydrol. Earth Syst. Sci. Discuss., 4, 863-880, 2007

www.hydrol-earth-syst-sci-discuss.net/4/863/2007/

(C) Author(s) 2007. This work is licensed

under a Creative Commons License.

A method to

determine plant water source

L. B. Menchaca et al.

\title{
A method to determine plant water source using transpired water
}

\author{
L. B. Menchaca ${ }^{1}$, B. M. Smith ${ }^{2}$, J. Connolly ${ }^{3}$, M. Conrad ${ }^{4}$, and B. Emmett ${ }^{5}$ \\ ${ }^{1}$ Geography Department, University of California Berkeley, CA 94720, USA \\ ${ }^{2}$ Isotope Solutions Inc., 1126 Delaware, Berkeley CA, 94702, USA \\ ${ }^{3}$ University College Dublin, School of Mathematical Sciences, Belfield, Dublin 4, Ireland \\ ${ }^{4}$ Lawrence Berkeley National Laboratory, Berkeley, CA 94720, USA \\ ${ }^{5}$ Centre for Ecology and Hydrology, Bangor, Gwynedd, LL57 2UP, UK
}

Received: 17 January 2007 - Accepted: 19 February 2007 - Published: 18 April 2007

Correspondence to: B. Emmett (bae@ceh.ac.uk)

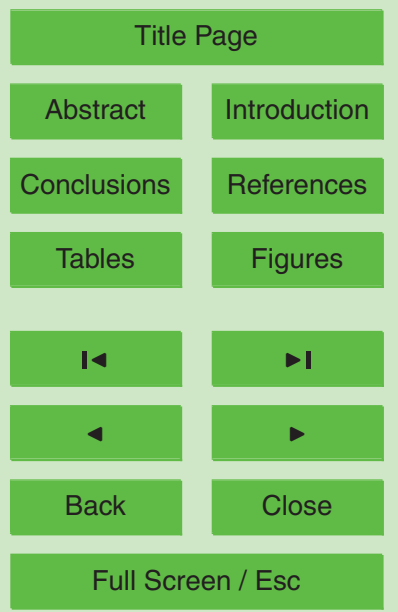

Printer-friendly Version

Interactive Discussion 


\section{Abstract}

A method to determine the stable isotope ratio of a plant's water source using the plant's transpired water is proposed as an alternative to standard xylem extraction methods. The method consists of periodically sampling transpired waters from shoots or leaves enclosed in sealed, transparent bags which create a saturated environment, preclude further evaporation and allow the progressive mixing of evaporated transpired water and un-evaporated xylem water. The method was applied on trees and shrubs coexisting in a non-irrigated area where stable isotope ratios of local environmental waters are well characterized. The results show Eucalyptus globulus (tree) and Genista monspessulana (shrub) using water sources of different isotopic ratios congruent with groundwater and soil water respectively. In addition, tritium concentrations indicate that pine trees (Pinus sylvestris) switch water source from soil water in the winter to groundwater in the summer. The method proposed is particularly useful in remote or protected areas and in large scale studies related to water management, environmental compliance and surveillance, because it eliminates the need for destructive sampling and greatly reduces costs associated with laboratory extraction of xylem waters from plant tissues for isotopic analyses.

\section{Introduction}

Traditional approaches to obtain samples of soil water or shallow groundwater for stable isotopic or tritium analyses have focused on intrusive sampling methods. These include drilling wells, using hydro-punches, or excavating the earth and obtaining water samples through pumping, using vacuum lysimeters, or removing the water from soils using physical methods. Similarly, traditional approaches to obtain samples of plant xylem waters for isotopic characterization involve destructive sampling of woody plant material such as tree trunk coring or clipping of branches followed by distillation or other water extraction method.

\section{HESSD}

4, 863-880, 2007

A method to

determine plant water source

L. B. Menchaca et al.

Title Page

Abstract

Introduction

Conclusions

Tables

References

Figures

14

$\rightarrow 1$

4

Back

Close

Printer-friendly Version

Interactive Discussion 
Stable isotopes techniques to determine plant water sources are robust and widely applied in plant ecology. Researchers have obtained water samples from various plant tissues for purposes of studying the isotopic compositions of the waters. Plant xylem water is used in numerous studies to determine the stable isotopic compositions of 5 hydrogen and oxygen in shallow environmental waters and it has been shown that plant xylem water is not isotopically fractionated during root uptake and transport to the plant leaf (EhEhleringer and Dawson, 1992; Dawson, 1993; Dawson et al. 2002; Wershaw et al., 1966). Bulk leaf water is not useful in these studies because it becomes enriched in the heavy isotopes of hydrogen and oxygen due to evaporative 10 fractionation. Because the amount of heavy isotope enrichment in water extracted from the leafy tissues of plants depends on such factors as transpiration rate, humidity, wind velocity, plant species, and local soil conditions, it is difficult to accurately predict the degree of heavy isotope enrichment in the leaves of a given plant. The theoretical aspects of stable isotope relationships in plant leaf tissue have been extensively 15 studied. The difficulty in accurately modeling or predicting the stable isotopic compositions of leaf water due to compartmentalization, and perhaps to species-dominated and capacitance-related effects (Stewart et al., 1972; Gonfiantini, Italy; Dongmann et al., 1974; Cooper and DeNiro, 1989; Edwards, 1993) has been emphasized. The theory and modeling of stable isotope relations in transpired water is complex and precise pexisting models require stable isotopic analysis of plant stem water and atmospheric water vapor. Published reports establish that transpired waters are isotopically disturbed, with non-equilibrium enrichments in the heavy isotopes of hydrogen and oxygen due to evaporation during water residence in the plant leaf.

Because mass dependent fractionation of light isotopes depends only on the rela25 tive masses of the fractionating isotopes, tritium fractionation (the radioactive hydrogen isotope) in the leafy materials of plants is expected to be $50 \%$ stronger than deuterium fractionation under equilibrium conditions, and $33 \%-50 \%$ stronger than deuterium fractionation under disequilibrium conditions according to reports by the International Atomic Energy Agency IAEA(IAEA, 1965; Dongman et al, 1974; IAEA 1962;
HESSD

4, 863-880, 2007

\section{A method to \\ determine plant water source}

L. B. Menchaca et al.

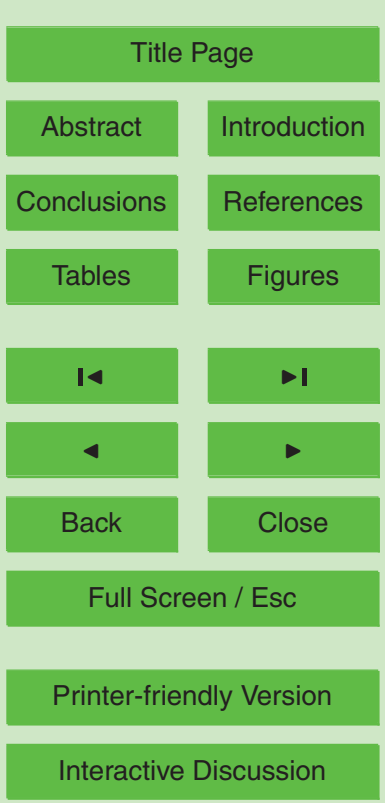

EGU 
IAEA, 1979). These reports show that one can determine the distribution of tritium in shallow subsurface waters by conducting tritium activity measurements of plant xylem waters.

Practically, as past studies have shown that transpired water from plant leaves is 5 fractionated, it is necessary to extract xylem water from plant stems to determine the stable isotopic signatures of the plant water source. Therefore, to accurately determine the stable isotopic compositions of hydrogen and oxygen and the tritium concentrations of soil and shallow groundwaters using analytical data for transpired waters, it is first necessary to determine the amount of evaporative fractionation that has occurred dur10 ing water residence in the plant leaf. In this study we suggest a method of sampling transpired waters, followed by an analytical approach, and a data interpretation technique that allow the determination of evaporative fractionation. This in turn allows the identification of the stable isotopic compositions and tritium activities of plant xylem waters and isotopically equivalent soil waters and/or shallow groundwaters being used 15 by the plant.

\section{Site description and methodology}

The study took place in the city of Berkeley, California within the Lawrence Berkeley National Laboratory grounds. The location's hydrogeology is well characterized and basic information has already been obtained on the stable isotope characteristics of 20 meteoric waters, surface waters and groundwaters by the US Department of Health Services as reported in DHS, AIP, 1995 (Lawrence Berkeley Laboratory Report, 1994; Lawrence Berkeley Laboratory Report 1993; Agreement in Principle, 1995). At the study site, there is a marked stable isotope contrast between facility water $\left(\delta^{18} \mathrm{O}=\right.$ -12 to $-13 \%$ o), soil water ( -7 to $-8 \%$ ), groundwaters ( -6 to $-7 \%$ ) and rainfall for $1992-$ $251993(-6$ to $-7 \%$ ) with weighed mean value of -6.5 and a local meteoric water line of $\delta \mathrm{D}=8.12\left(\delta^{18} \mathrm{O}\right)+9.92$. Table 1 is a summary of the isotopic characteristics of various waters at the Berkeley Lab site (Smith et al., 1993; Smith and Menchaca, 1994;

\section{HESSD}

4, 863-880, 2007

A method to

determine plant water source

L. B. Menchaca et al.

Title Page

Abstract

Introduction

Conclusions

Tables

References

Figures

14

$\rightarrow$

4

Back

Close

Full Screen / Esc

Printer-friendly Version

Interactive Discussion 
Smith and Menchaca, 1999). These contrasting values make it possible to discriminate between these possible water sources in plants

Water samples of transpired water were transferred to an analytical laboratory equipped with a gas-source mass spectrometer, where they were analyzed for sta5 ble isotopic ratios of hydrogen $\delta \mathrm{D}$ and $\delta^{18} \mathrm{O}$. The hydrogen isotope compositions were determined on hydrogen gas prepared by reduction over zinc at $400^{\circ} \mathrm{C}$. The oxygen isotope rations were determined on waters equilibrated with $\mathrm{CO}_{2}$ overnight at $25^{\circ} \mathrm{C}$. The hydrogen and oxygen stable isotope ratios are expressed as $\delta \mathrm{D}$ and $\delta^{18} \mathrm{O}$ values in (per mil or parts-per-thousand) differences from the stable isotopic composition of 10 V-SMOW (Vienna-Standard Mean Ocean Water). Pine tree transpired water samples were analyzed for Tritium concentrations determined by scintillation counting. Stable isotope analytical results of the plant transpired water samples collected are presented in Tables 2 and 3 . To determine $\delta \mathrm{D}, \delta^{18} \mathrm{O}$ and tritium in plant water source the steps below were followed:

1. Collect samples of transpired water from a plant in a time series manner from within a sealed plastic bag (or gas chamber) as described in the methodology section above.

2. Determine the stable isotopic composition and tritium activities of the plant transpired waters collected.

3. Plot the stable isotopic compositions of the transpired waters together with a local Meteoric Water Line or Global Meteoric Water Line on a Cartesian graph of $\delta \mathrm{D}$ vs $\delta^{18} \mathrm{O}$.

4. Construct a regression mixing line of best fit of the transpired water stable isotopic data.

5. Determine the stable isotopic compositions of xylem water or subsurface water (plant water source) from the point of intersection of the transpired water regression mixing line and the local or Global Meteoric Water Line.

\section{HESSD}

4, 863-880, 2007

A method to

determine plant water source

L. B. Menchaca et al.

Title Page

Abstract

Introduction

Conclusions

Tables

References

Figures

14

4

Back

Close

Full Screen / Esc

Printer-friendly Version

Interactive Discussion 
6. Determine the amount of evaporative fractionation of $\delta \mathrm{D}$ and $\delta^{18} \mathrm{O}$ in transpired water samples as the difference between the $\delta \mathrm{D}$ value of the most evaporated transpiration water sample and the $\delta \mathrm{D}$ value at the intersection point with the local or Global Meteoric Water Line.

7. Calculate the amount of evaporative tritium enrichment by inference from the amount of deuterium fractionation per transpired water sample and the well known mass dependence of light isotopic fractionation.

8. Calculate the relative contribution of source water (xylem water) in every sample of transpired water through time can then be estimated using a mass balance equation for a two end-member regression mixing line.

Approximate standard errors can be computed for estimates of the points of intersection. Let the meteoric line be $\delta \mathrm{D}=\mathrm{a}_{m}+\mathrm{b}_{m} \delta^{18} \mathrm{O}$ and let the estimated line from the experiment be $\hat{\delta} \mathrm{D}=\hat{a}+\hat{b} \delta^{18} \mathrm{O}$ ( $\mathrm{A} \wedge$ above a coefficient means that it is an estimate). Here $a_{m}$ and $b_{m}$ are known constants whereas $\hat{a}$ and $\hat{b}$ are estimated from the regression analysis of the data. The residual variance from the regression analysis is $\mathrm{s}^{2}$. The coordinates for the point of intersection of the two lines are $\hat{\delta}^{18} O$ and $\hat{\delta} D$. We use the notation that $n$ is the number of samples, $x_{1} \ldots x_{n}$ are the values of $\delta^{18} O$ at each of the sample points and $\bar{x}$ is the average value of $\delta^{18} O$ in the study. An approximate estimate of the standard error of $\hat{\delta}^{18}$ Oat the point of intersection can be calculated using the Delta method (Efron and Tibshirani, 1998) as:

$\operatorname{se}\left(\hat{\delta}^{18} \mathrm{O}\right) \approx s \hat{\delta}^{18} \mathrm{O}\left[\frac{1}{n\left(a_{m}-\hat{a}\right)^{2}}+\frac{1}{\sum_{i}\left(x_{i}-\bar{x}\right)^{2}}\left[\frac{\bar{x}}{a_{m}-\hat{a}}-\frac{1}{\hat{b}-b_{m}}\right]^{2}\right]^{0.5}$

Design to reduce the standard error $\operatorname{se}\left(\hat{\delta}^{18} \mathrm{O}\right)$ : the standard error formula above depends on many variables, some of which may be manipulated to reduce the size of the

\section{HESSD}

4, 863-880, 2007

A method to

determine plant water source

L. B. Menchaca et al.

Title Page

Abstract

Introduction

Conclusions

References

Tables

Figures

14

$\rightarrow$

4

Back

Close

Full Screen / Esc

Printer-friendly Version

Interactive Discussion 
standard error. The variables that can be influenced by the experimenter are $\mathrm{n}, \bar{x}$ and $\sum_{i}\left(x_{i}-\bar{x}\right)^{2}$. Increasing $n$ (taking more samples) will reduce both terms within the main parentheses in the formula. Increasing the range of the $x$ values (the observed $\delta^{18} \mathrm{O}$ values in successive samples) will also increase $\sum_{i}\left(x_{i}-\bar{x}\right)^{2}$ and hence act to reduce

5 the size of the second term within the main parentheses. It will also affect $\bar{x}$. The minimum possible $x$ value is the $\delta^{18} \mathrm{O}$ value at the point of intersection.

\section{Results and discussion}

A shoot of a eucalyptus tree, a French broom shrub and two pines living in close proximity to each other ( within $10 \mathrm{~m}$ ratio) was enclosed and sealed into a transparent 10 plastic bag. Transpiration water was let to accumulate inside the bags for $24 \mathrm{~h}$. The water was then drained out from a small drain hole which was subsequently re-sealed. A $20 \mathrm{ml}$ aliquot of the accumulated transpired water was taken for analysis. This procedure was repeated every $24 \mathrm{~h}$. Six sequential transpired water samples were obtained from Eucalyptus globulus, 4 samples from Genista monspessulana and 6 to 7 samples

from Pinus sylvestris during the dry and rainy seasons (only one pine tree was sampled during summer).

The first-collected transpired water samples for each plant were found to lie the farthest to the right of the local meteoric water line, indicating that they contain the largest components of evaporated leaf water. The isotopic values of this first and most evaporated transpired water sample was $\delta^{18} \mathrm{O}=-0.5$ and $\delta \mathrm{D}=-17.9$ for eucalyptus, and $\delta^{18} \mathrm{O}=-1.9$ and $\delta \mathrm{D}=-22.8$ for French broom. Successive samples for each plant were found to be closer to the local meteoric water line because they contained progressively larger components of un-evaporated xylem water. The $\delta \mathrm{D}$ and $\delta^{18} \mathrm{O}$ values for each plant were seen to become more negative from the first sample to the sixth sample for

\section{HESSD}

4, 863-880, 2007

\section{A method to \\ determine plant water source}

L. B. Menchaca et al.

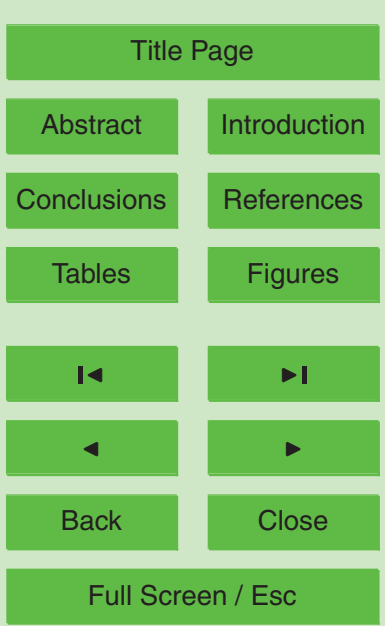

Printer-friendly Version

Interactive Discussion that $\delta^{18} \mathrm{O}$ values in xylem (source water) were -6 for eucalyptus and $-7.8 \%$ o for French 
broom (as indicated above, by the intersection between the local meteoric water line and each of the plant's evaporation-mixing line), the proportion (\%) of xylem water in each successive transpired water sample can be calculated as: $X=1-\{(\mathrm{Ces}-\mathrm{Cs}) /(\mathrm{Ce}-$ $\mathrm{Cs})\}$, where $\mathrm{Cs}=$ xylem or water source $\delta^{18} \mathrm{O}$ or $\delta \mathrm{D}, \mathrm{Ce}=$ first and most evaporated 5 sample, and Ces $=\delta^{18} \mathrm{O}$ or $\delta \mathrm{D}$ value of each mixed successive transpired water sample (Table 2).

The $\delta \mathrm{D}$ vs $\delta^{18} \mathrm{O}$ plot in Fig. 1 shows the Local Meteoric Water Line $\mathrm{D}=9.92+8.12$ $\left(\delta^{18} \mathrm{O}\right)$ together with regression lines for the stable isotope ratios obtained for Eucalyptus transpired water $\delta \mathrm{D}=-18.07+3.66\left(\delta^{18} \mathrm{O}\right)$ and French broom $\delta \mathrm{D}=-14.11+$ $104.75\left(\delta^{18} \mathrm{O}\right)$. Extrapolation of the plant transpired water regression lines to intercept the local meteoric water line give intercepting points at $\hat{\delta}^{18} O=-6.28 \%$ of eucalyptus and $\hat{\delta}^{18} O=-7.12 \%$ 。 for French broom. As indicated in table 1, these intercepting values fall within the range of stable isotopic ratios typical of groundwater ( -6 to -7$)$ and soil water or vadose zone $(-7$ to -8$)$ at LBNL. These results suggest that groundwater is 15 the source for eucalyptus and soil water is the source for French broom. Approximate values for $\operatorname{se}\left(\hat{\delta}^{18} O\right)$ for Eucalyptus and Genista are 0.466 and 0.527 respectively. The standard errors are large and the difference between the two estimated $\delta^{18} \mathrm{O}$ values is not significant ( $\mathrm{t}$ value $=1.2$ with 6 degrees of freedom).

We evaluated the effect of increasing the range in the $x$ values on se $\left(\hat{\delta}^{18} \mathrm{O}\right)$ by 20 supposing that the observed $x$ values are scaled so the largest $x$ value is that observed at the first sampling and the smallest is that at the point of intersection of the two lines and the remaining values are scaled to retain their relative position as in the observed $x$ series. The effect of this would be to reduce the standard errors for the two examples from 0.466 to 0.285 for the Eucalyptus data and from 0.627 to 0.147 for the Genista data. Comparing the two estimated $\delta^{18} \mathrm{O}$ values at the point of intersection using these standard errors would give a t value $=2.64$ with approximately 6 degrees of freedom, which would be significant at the $5 \%$ level. Thus, the precision of the method can be considerably improved by prolonging the sampling period, which may both increase the number of samples and increase the range of the observed $\delta^{18} \mathrm{O}$ values.

HESSD

4, 863-880, 2007

\section{A method to \\ determine plant water source}

L. B. Menchaca et al.

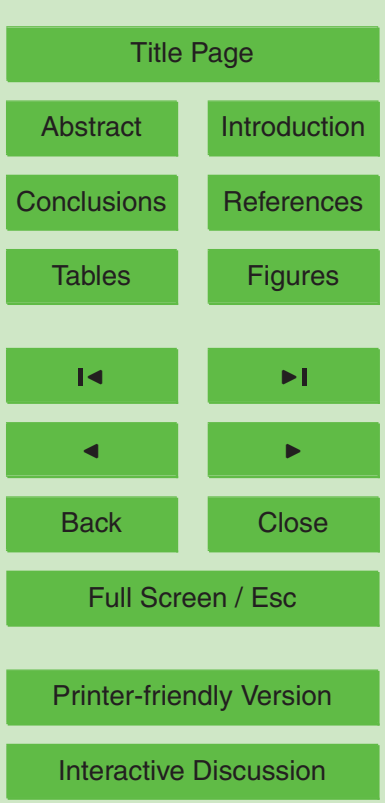

EGU 
Isotopic techniques have been clearly demonstrated in published studies where plants are shown to switch between water sources, either seasonally according to water availability, or in response to other environmental or physiological factors. We determined tritium concentrations in transpired water samples from pine trees during

5 a winter and a summer season. Tritium activities in waters collected from wells and lysimeters in the area are well characterized. LBNL systematically monitors these waters for environmental compliance purposes and the data is published in their annual environmental reports. During this study, wells located near these pine trees were reported as having waters with low tritium activities below $10000 \mathrm{pCi} / \mathrm{L}$. Lysime10 ter or soil waters in contrast were shown to have higher values, sometimes as high as $40000 \mathrm{pCi} / \mathrm{L}^{14}$. Figure 2 shows tritium values found in transpired water from the pine trees sampled. Low tritium concentration values between $5000 \mathrm{pCi} / \mathrm{L}$ and $10000 \mathrm{pCi} / \mathrm{L}$ were found in the summer, and high tritium values between 13000 and $38000 \mathrm{pCi} / \mathrm{L}$ were found in the winter (see Fig. 2a). The transpired water tritium values in winter are congruent with tritium values found in soil waters, while the low tritium values found in the summer are congruent with groundwater values. There is little moisture available in the shallow soil layers during summers at the site, and tree roots in the deeper zones may become more active.

A combined plot of the local meteoric water line and the $\delta \mathrm{D}$ vs $\delta^{18} \mathrm{O}$ transpired water 20 mixing line for summer transpired water values was constructed as described above. The plot (see Fig. 2b) shows the intercept between the $\delta \mathrm{D}$ vs $\delta^{18} \mathrm{O}$ transpired water mixing line and the LMWL at a $\delta^{18} \mathrm{O}$ value of $\sim-5.7 \%$. This stable isotopic signature is indicative of springs or groundwater according to the values in Table 1. The stable isotope results re-enforce the conclusion suggested by the tritium concentration results, that these trees were using groundwaters in the summer at the time of sampling. During the winter, tritium concentrations in the transpired water samples were high, reflecting the values reported for lysimeters at the site. In the winter, or rainy season, the soils in the study area are saturated and not surprisingly the shallow roots of these pines may become more active. In this study we did not obtain stable isotope data for
HESSD

4, 863-880, 2007

\section{A method to \\ determine plant water source}

L. B. Menchaca et al.

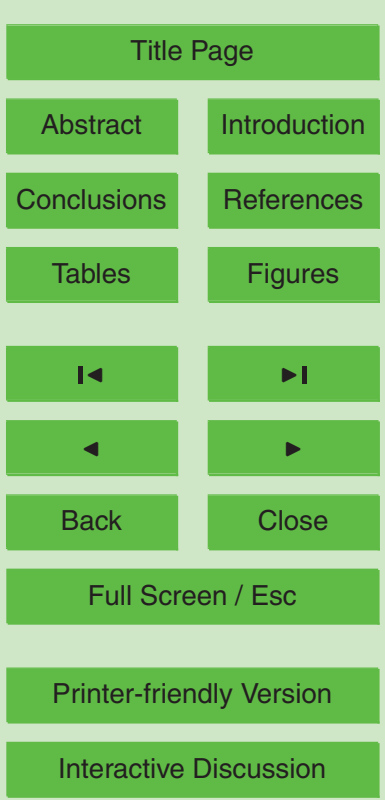

EGU 
the pine transpired water samples in the winter. However, the combined stable isotope data for the summer and tritium concentration data for summer and winter give a strong indication that the pine trees studied at the site switch water source from groundwater in summer to soil water in winter.

The magnitude of evaporative enrichment in deuterium (or ${ }^{18} \mathrm{O}$ ) is determined by comparing the $\delta \mathrm{D}$ or $\delta^{18} \mathrm{O}$ value of the first collected (or any other) sample with the projected composition of the un-fractionated xylem water as illustrated in Fig. 1. Once the magnitude of deuterium fractionation has been determined, the amount of evaporative enrichment for tritium can be calculated based on the well known mass dependence 10 of light isotope fractionation. The relative tritium-hydrogen and deuterium-hydrogen isotope fractionation effects for kinetic and equilibrium processes have been reported to range from 1.33 to 1.50 . Evaporative tritium enrichment is, therefore, $33 \%$ to $50 \%$ larger than that determined for deuterium. With this knowledge, the tritium activity measured in any sample of transpired water can be corrected to account for evaporative tritium fractionation at the plant leaf.

The first transpired water samples taken from Eucalyptus globulus and Genista monspessulana are enriched in deuterium by $22.1 \%$ and $35.2 \%$, respectively (see Fig. 1). If mass dependent ${ }^{3} \mathrm{H}$ fractionation is assumed to be $50 \%$ stronger than ${ }^{2} \mathrm{H}$ fractionation, the tritium activities of the first collected samples require downward correction by 33.1 and 52.8 , respectively. Thus, for the plant species investigated, the tritium activities in first-collected samples require only minor downward corrections of $3-5 \%$ to represent xylem water values and subsurface soil water or shallow groundwater values. Larger corrections may be required in arid regions where evaporative deuterium and tritium enrichments may be more pronounced or for plant species that contain a 25 larger component of evaporated water in leafy tissue.

The method described here relies strongly on being able to determine the intersecting point between a local or global meteoric water line and a transpired water line that describes a mixing of evaporated and non-evaporated components. The closer the transpired water line data points get to the intersection with the meteoric water line,

HESSD

4, 863-880, 2007

\section{A method to \\ determine plant water source}

L. B. Menchaca et al.

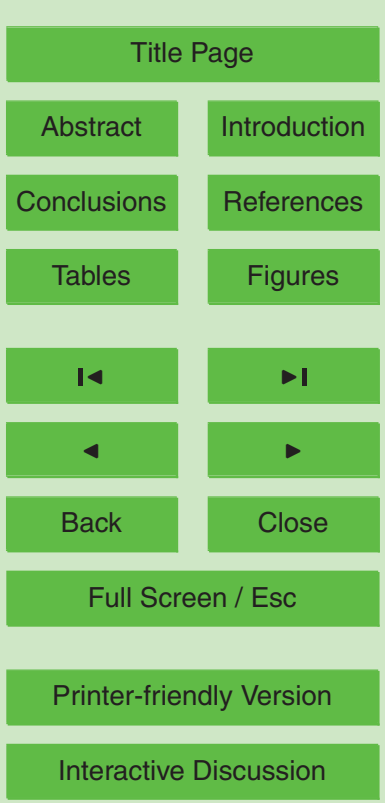

EGU 
the lesser the standard error will be and the lower degree of uncertainty as to where exactly this intersecting point lies. This can be accomplished by increasing the number of samples (points on the transpired water regression line) or by sampling at longer time intervals. In cases where reducing costs is imperative, the later option may be 5 preferred.

The ability to infer the isotopic compositions and/or tritium concentrations of plant xylem and subsurface water source without the need for destructive sampling of the plant or the soil eliminates the sample preparation steps required to separate xylem waters from solid plant materials and makes the method very undemanding and practical.

10 This method is particularly useful in remote or protected study areas where equipment installation is difficult or not permitted. The extraction of waters from plants is typically accomplished by approaches such as heating coupled with cryogenic trapping or azeotropic distillation with an organic solvent such as toluene, hexane, ether, etc., with significant safety and health hazards, requirements for highly skilled laboratory work-

ers, and hazardous waste generation. The method we propose is simpler, requires only moderate energy, is thus less demanding on energy supplies and workers time, and is generally less damaging to plants, safer to humans, and inexpensive.

\section{Conclusions}

The proposed method allows attribution of water sources used by different species

and their seasonal variation at minimal preparation cost, use and production of toxic chemical and damage to vegetation.

Acknowledgements. This study was partially funded with US government support under the Management and Operations Contract \#DE-ACO3-76SF0098, awarded by the Department of Energy. We specially thank A. Templeton and A. Davi for their work on stable isotope and tritium
HESSD

4, 863-880, 2007

A method to

determine plant water source

L. B. Menchaca et al.

Title Page

Abstract

Introduction

Conclusions

Tables

References

Figures

14

$\rightarrow 1$

Back

Close

Printer-friendly Version

Interactive Discussion

Sadly, B. M. Smith passed away in August 2006. This paper is dedicated to his memory in fond recollection and deepest appreciation for irreplaceable times in Berkeley and for his years 
of dedication to isotope geochemistry and his advocacy to the use of isotope techniques in support of environmental protection regulatory programs.

\section{References}

Agreement in Principle (AIP).: State of California, Department of Health Services, 1995. Annual Report, California, September 30, 1995

Cooper, L. E. and DeNiro, M. J.: Covariance of oxygen and hydrogen isotopic compositions in plant water, species effects, Ecology., 70(6) 1619-1628, 1989

Dawson, T. E.: Water sources as determined from xylem-water isotopic composition: perspectives on plant competition, distribution, and water relations, pages 465-496, in: Stable 10 isotopes and plant carbon-water relations Academic Press, edited by: Ehleringer, J. R., Hall, A. E., and Farquhar, G. D., San Diego, California, USA. 1993

Dawson, T. E., Mambelli, S., Plamboek, A. H., Templer, P. H., and Tu, K. P.: Stable isotopes in plant ecology, Annu. Rev. Ecol. Syst., 33, 507-559, 2002.

Dongmann, G., Nürnberg, H. W., Förstel, H., and Wagener, K.: On the enrichment of $\mathrm{H}_{2}{ }^{18} \mathrm{O}$ in the leaves of transpiring plants, Rad. Environm. Biophys., 11, 41-52, 1974.

Edwards, T. W. D.: Interpreting past climate from stable isotopes in continental organic matter, in: Stewart P.K., et al. Climate change in isotopic continental records, American Geophysical Union, Geophys. Monograph., 78, 331-341, 1993

Efron, B. and Tibshirani, R. J.: An introduction to the bootstrap. Chapman and Hall, London, pp. 436, 1998.

Ehleringer, J. R. and Dawson, T. E.: Water uptake by plants: perspectives from stable isotope composition. Plant, Cell, Environ. 15, 1073-1082, 1992.

Environmental tritium in trees, IAEA Report.: WM-232/44, 405-418, 1979.

Gonfiantini, R., Gratziu, S., and Tongiorgi, E.: Oxygen isotopic composition in leaves, in: Use of isotopes and radiations in soil-plant nutrition studies. Technical Report Series No. 206. Isotopic Atomic Energy Commission, Vienna , 405-410, 1965.

Isotopes and radiation in soil-plant nutrition studies, IAEA Report.: 410-415, 1965.

Lawrence Berkeley Laboratory, 1994.: Lawrence Berkeley Laboratory Site Environmental Report 1993, LBL-27170 (1995) UC-600, 1994.

\section{HESSD}

4, 863-880, 2007

\section{A method to \\ determine plant water source}

L. B. Menchaca et al.

Title Page

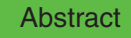

Introduction

Conclusions

References

Tables

Figures

14

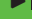

4

Back

Close

Full Screen / Esc

Printer-friendly Version

Interactive Discussion 
Lawrence Berkeley Laboratory, 1995.: Lawrence Berkeley Laboratory Site Environmental Report 1994, LBL-27170 (1995) UC-600, 1995.

Smith, B. M. and Menchaca L. B.: Method for determination of ${ }^{18} \mathrm{O} /{ }^{16} \mathrm{O}$ and ${ }^{2} \mathrm{H} /{ }^{1} \mathrm{H}$ ratios and ${ }^{3} \mathrm{H}$ (tritium) concentrations of xylem waters and subsurface waters using time series sampling, United States Patent No. 5, 979, 228, 1999.

Smith, B. M., Menchaca L. B., and Conrad, M.: LBNL Site- Restoration Internal Report unpublished. Stable isotopic characterization of waters at the Lawrence Berkeley National Laboratory, California, 1993.

Smith, B. M. and Menchaca, L. B.: Demonstration of stable isotope tracer methods in detailed hydrogeologic modeling and monitoring, in: Lawrence Berkeley Laboratory, 1994. Internal Report. Laboratory directed research and development program, PUB 5401, 29-31, 1994.

Stewart, G. L., Wyerman, T. A., Sherman , M., and Schneider, R.: Tritium in pine trees from selected locations in the United States, including areas nuclear facilities, geological survey research, U.S. Geol. Survey Prof. Paper, 800-B, pp. B265-B271, 1972.

Tritium in the physical and biological sciences, 1, IAEA Report No. ST1/PUB/39: 161, 1962.

Wershaw, R. L., Friedman, I., Heller, S. J., and Frank, P. A.: Hydrogen isotopic fractionation of water passing through trees, in: Advances in organic geochemistry, proceedings of the Third International Congress Pergamon Press, edited by: Hobson, G. D. and Speers, G. C., 55-67, 1966.

\section{HESSD}

4, 863-880, 2007

A method to

determine plant water source

L. B. Menchaca et al.

Title Page

Abstract

Introduction

Conclusions

References

Tables

Figures

14

I

4

Back

Close

Full Screen / Esc

Printer-friendly Version

Interactive Discussion 


\section{HESSD}

4, 863-880, 2007

\section{A method to}

determine plant water source

L. B. Menchaca et al.

Table 1. Characteristic $\delta^{18} \mathrm{O}$ signatures of waters at the Lawrence Berkeley Laboratory during 1993-1994.

Rainfall mean value: $-6.5 \%$

\begin{tabular}{ll}
\hline Type of Waters & ${ }^{18} \mathrm{O}$ in $\%$ \\
\hline Springs & -6 to -6.5 \\
Groundwaters & -6 to -7 \\
Vadose Zone Water & -7 to -8 \\
Tap Water & -12 to -13 \\
Rain & -2 to -14 \\
\hline
\end{tabular}

Title Page

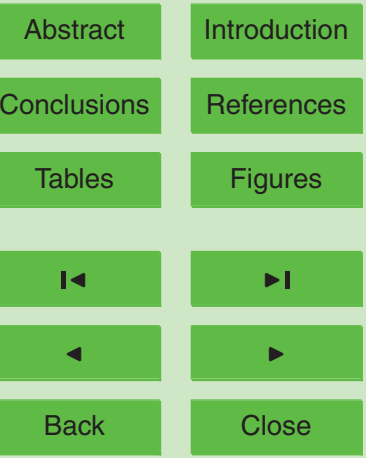

Full Screen / Esc

Printer-friendly Version

Interactive Discussion 


\section{HESSD}

4, 863-880, 2007

Table 2. Stable Isotopic composition of transpired water samples from Genista monspessulana and Eucalyptus globulus and proportion of xylem water in each sample.

\begin{tabular}{llllll}
\hline Sample & Species & Day & $\begin{array}{l}\delta^{18} \mathrm{O} \\
(\% \circ)\end{array}$ & $\begin{array}{l}\delta \mathrm{D} \\
(\% \circ)\end{array}$ & $\begin{array}{l}\text { Xylem } \\
(\%)\end{array}$ \\
\hline E1 & E. globulus & 1 & -0.5 & -17.9 & 0.0 \\
E2 & E. globulus & 2 & -1.3 & -24.5 & 14.6 \\
E3 & E. globulus & 3 & -2.8 & -27.9 & 41.8 \\
E4 & E. globulus & 4 & -3.3 & -32.9 & 50.9 \\
E5 & E. globulus & 5 & -4.3 & -33.0 & 69.1 \\
E6 & E. globulus & 6 & -4.6 & -35.0 & 74.6 \\
& & & & & \\
FB1 & G. monspessulana & 1 & -1.9 & -22.8 & 0.0 \\
FB2 & G. monspessulana & 2 & -3.3 & -30.2 & 27.5 \\
FB3 & G. monspessulana & 3 & -4.2 & -34.9 & 45.1 \\
FB4 & G. monspessulana & 4 & -4.6 & -35.0 & 52.9 \\
\hline
\end{tabular}

A method to

determine plant water source

L. B. Menchaca et al.

Title Page

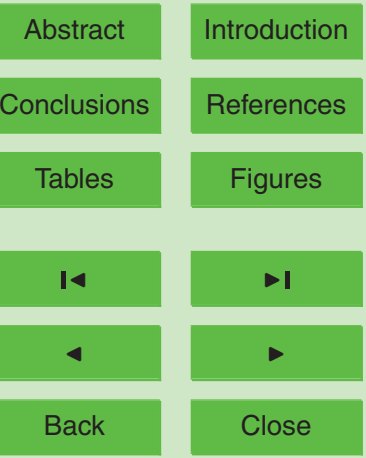

Full Screen / Esc

Printer-friendly Version

Interactive Discussion 


\section{HESSD}

4, 863-880, 2007

Table 3. Stable Isotopic compositions of transpired water from Pinus sylvestris.

A method to

determine plant water source

\begin{tabular}{lllll}
\hline Sample & Species & Day & $\begin{array}{l}\delta^{18} \mathrm{O} \\
(\% \circ)\end{array}$ & $\begin{array}{l}\delta \mathrm{D} \\
(\% \circ\end{array}$ \\
\hline 177C & Pinus sylvestris & 1 & -1.2 & -19.0 \\
\hline 177D & Pinus sylvestris & 1 & -1.8 & -14.0 \\
4710C & Pinus sylvestris & 4 & -3.1 & -20.9 \\
4710D & Pinus sylvestris & 4 & -0.6 & -12.0 \\
8714D & Pinus sylvestris & 8 & -1.1 & -16.0 \\
13719C & Pinus sylvestris & 13 & -3.7 & -27.0 \\
13719D & Pinus sylvestris & 13 & -1.3 & -15.0 \\
21727C & Pinus sylvestris & 21 & -3.9 & -27.0 \\
21727D & Pinus sylvestris & 21 & -1.8 & -15.0 \\
25731C & Pinus sylvestris & 25 & -4.0 & -30.0 \\
25731D & Pinus sylvestris & 25 & -1.4 & -17.0 \\
40815C & Pinus sylvestris & 40 & -2.7 & -24.0 \\
40815D & Pinus sylvestris & 40 & 0.5 & -5.0 \\
\hline
\end{tabular}

L. B. Menchaca et al.

Title Page

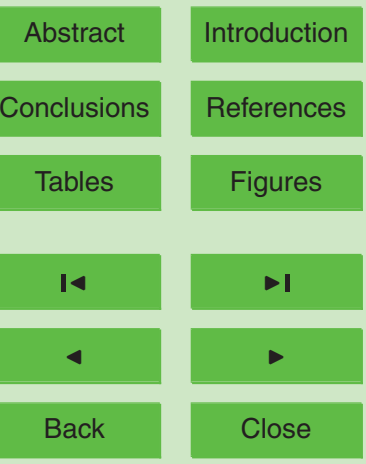

Full Screen / Esc

Printer-friendly Version

Interactive Discussion 


\section{HESSD}

4, 863-880, 2007

\section{A method to}

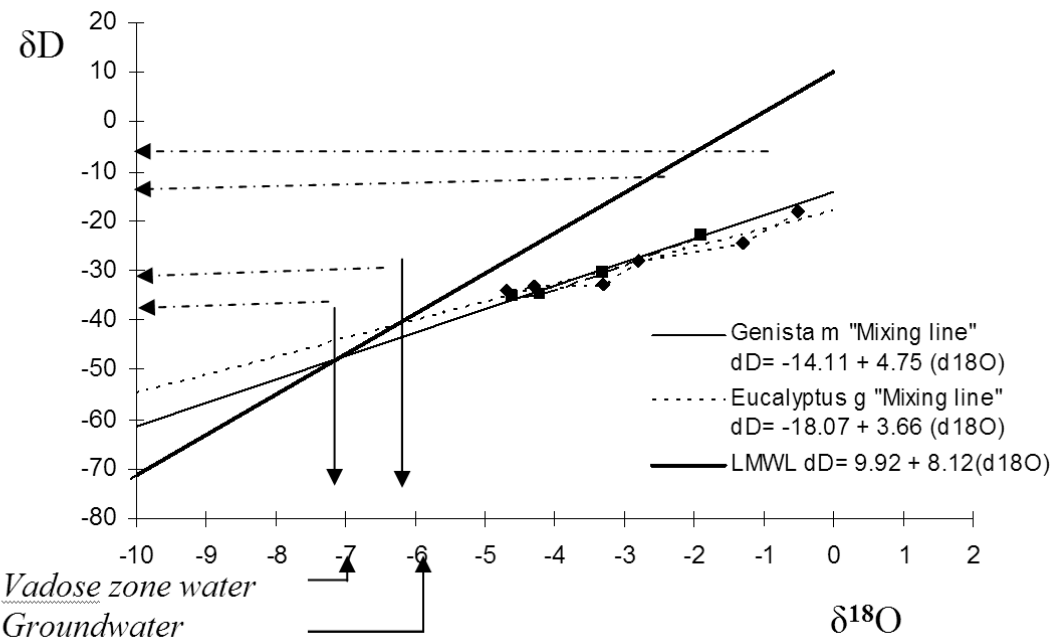

\section{determine plant water} source

L. B. Menchaca et al.

Title Page

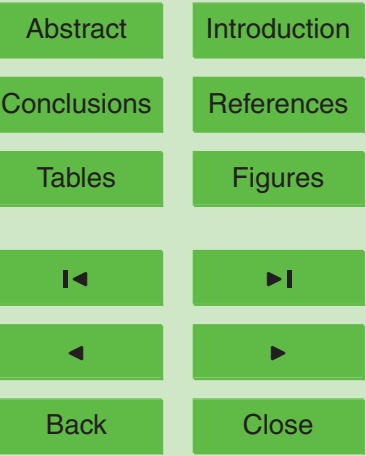

Full Screen / Esc

Printer-friendly Version

Interactive Discussion 
(a)

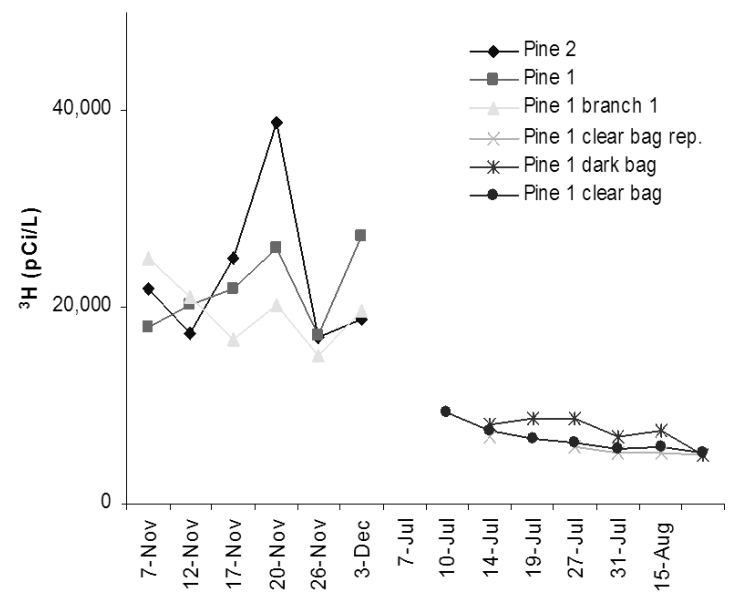

HESSD

4, 863-880, 2007

\section{A method to \\ determine plant water source}

L. B. Menchaca et al.

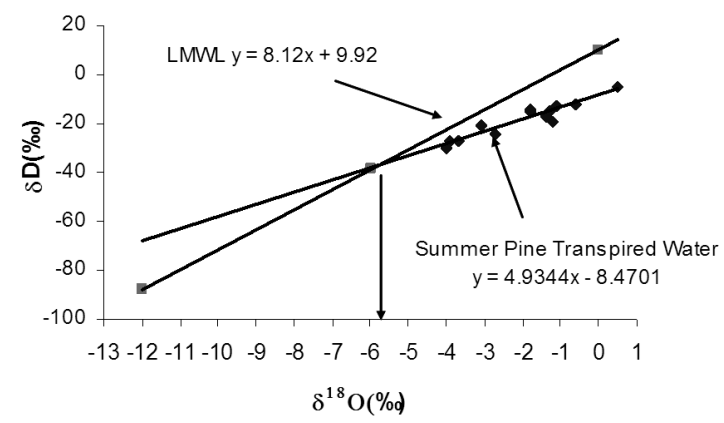

(b)

Fig. 2. (a) Summer and winter Tritium concentrations in transpired waters collected from pine trees growing approximately $300 \mathrm{~m}$ south of the National Tritium Labeling Facility at Berkeley, California. (b) Stable isotope ratios in pine transpired water samples collected during 7 July to 15 August 1995.

Title Page

Abstract

Introduction

Conclusions

References

Tables

Figures

I

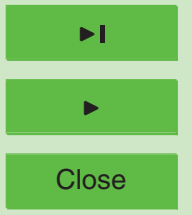

Back

Close

Full Screen / Esc

Printer-friendly Version

Interactive Discussion 